The Faune entomologique des environs de Paris appeared Sept. 26, 1835 .

The Faune de l'Océanie appeared May 9, 1835 .

Of the Species général des Lépidoptères, the first two livraisons appeared April ro, I 836 .

Boisduval and LeConté's Histoire générale et iconographie des Lépidoptères et des chenilles de l'Amérique septentrionale appeared in 26 livraisons and then terminated abruptly. The first eight livraisons were published in 1829-1830; there was then a break, and the remainder were issued in $1833-1834$. The livraisons were made up as follows, and I have added the exact dates of four of them :

$$
\begin{aligned}
& \text { (p. I-16; pl. 1-3) May 2, I829. } \\
& \text { (p. 17-24; pl. 4-6) June 13, I829. } \\
& \text { (p. 25-32; pl. 7-9). } \\
& \text { (p. 33-40; pl. 10-12). } \\
& \text { (p. 4I-48; pl. I3-15). } \\
& \text { (p. 49-56; pl. 16-18). } \\
& \text { (p. 57-64; pl. I9-21). } \\
& \text { (p. 65-8o; pl. 22-24). } \\
& \text { (p. 8I-88; pl. 25-27) July 27, I833. } \\
& \text { (p. 89-100; pl. 28-30) “ “" } \\
& \text { (p. IоI-Io8; pl. } 3^{\text {I-33). }} \\
& \text { (p. 109-116; pl. 34-36). } \\
& \text { (p. II7-I24; pl. 37-39). } \\
& \text { (p. I25-132; pl. 40-42). } \\
& \text { (p. I33-140; pl. 43-45). } \\
& \text { (p. I4I-148; pl. 46-48). } \\
& \text { (p. 149-1 56; pl. 49-5I). } \\
& \text { (p. I 57-164; pl. 52-54). } \\
& 9 \text { (p. I65-I72; pl. 55-57). } \\
& 20 \text { (p. 173-180; pl. 58-6o). } \\
& 2 \text { I (p. 18I-I88; pl. 6I-63). } \\
& 22 \text { (p. 189-196; pl. 64-66). } \\
& 23 \text { (p. 197-204; pl. 67-69). } \\
& 24 \text { (p. 205-212; pl. 70-72). } \\
& 25 \text { (p. 213-220; pl. 73-75). } \\
& 26 \text { (p. 22I-228; pl. 76-78). }
\end{aligned}
$$

\section{A CURIOUS CASE OF PROTECTIVE COLORATION.}

At Mesilla, N. M., on Aug. 15, 1897, sat down to rest while on a collecting excursion, and my eye fell on a clump of the whitish-green Baileya multiradiata, with its splendid orange composite flowers. In the middle of the clump was a vanessid pupa, while resting on one of the stems, about to cast its skin, was a sphingid larva. These objects caused me some surprise, as being (so far as I had yet known) foreign to the Baileya, and yet harmonizing perfectly with its peculiar color. The pupa was silver-color with a faint greenish tinge and a golden lustre, with the dorsal prominences and part of the antennal coverings ruddy golden. A beautiful and conspicuous object in the hand, it was hardly noticeable on the plant. So also with the larva, which was $35 \mathrm{~mm}$. long, pale whitish-green, nearly the color of the foliage; caudal horn very pale blue, with dorsal black specks; seven oblique lateral stripes, spiracular openings orange. Taking the larva home, I found that it would by no means eat Baileya, but it fed greedily on the foliage of Solanum elaeagnifolium. It was, in fact, an immature " tomato worm." The pupa, on Aug. 2I, gave forth an ordinary example of Pyrameis cardui; the larva must doubtless have wandered from an adjacent Sphaeralcea.

Now are we to suppose that the vanessid larva came to the Baileya to pupate, and the sphingid to exuviate, because they realized that they would be protected (i.e. inconspicuous) there?

T. D. A. Cockerell. Mesilla, N. M., Sept.7, 1897 .

\section{NOTE ON CYDOSIINAE.}

In view of $\mathrm{Mr}$. Cockerell's note on the larva of Cydosia (Psyche VIII., I30) we have now at least a partial idea of the young stages of both genera of the Cydosiinae of Smith. Messrs. Hulst and Smith have both remarked on stage I. of Cerathosia (Ent. Amer. V. 48-9), but between the two accounts the essential features seem to have become befogged. The specimens are now before 

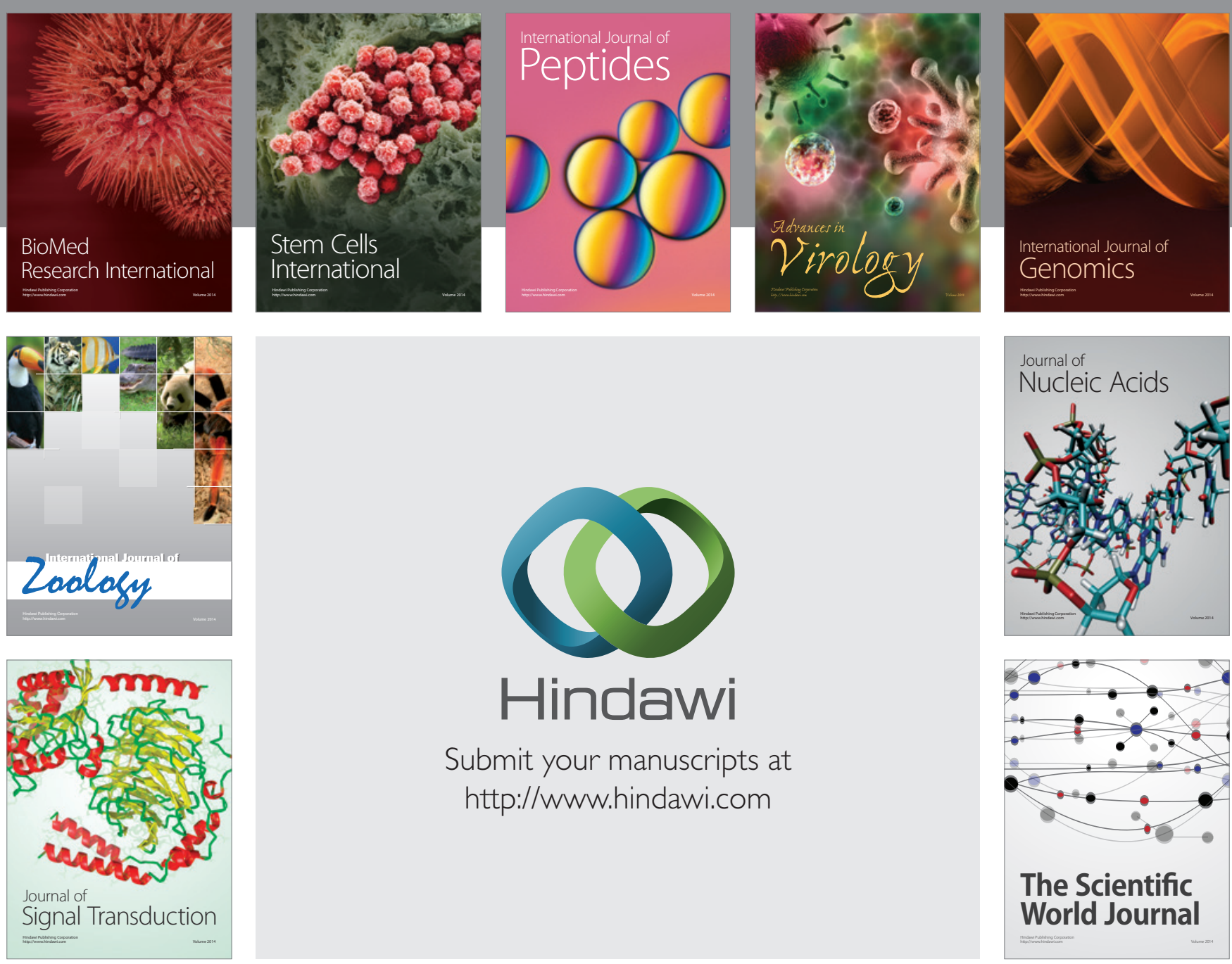

Submit your manuscripts at

http://www.hindawi.com
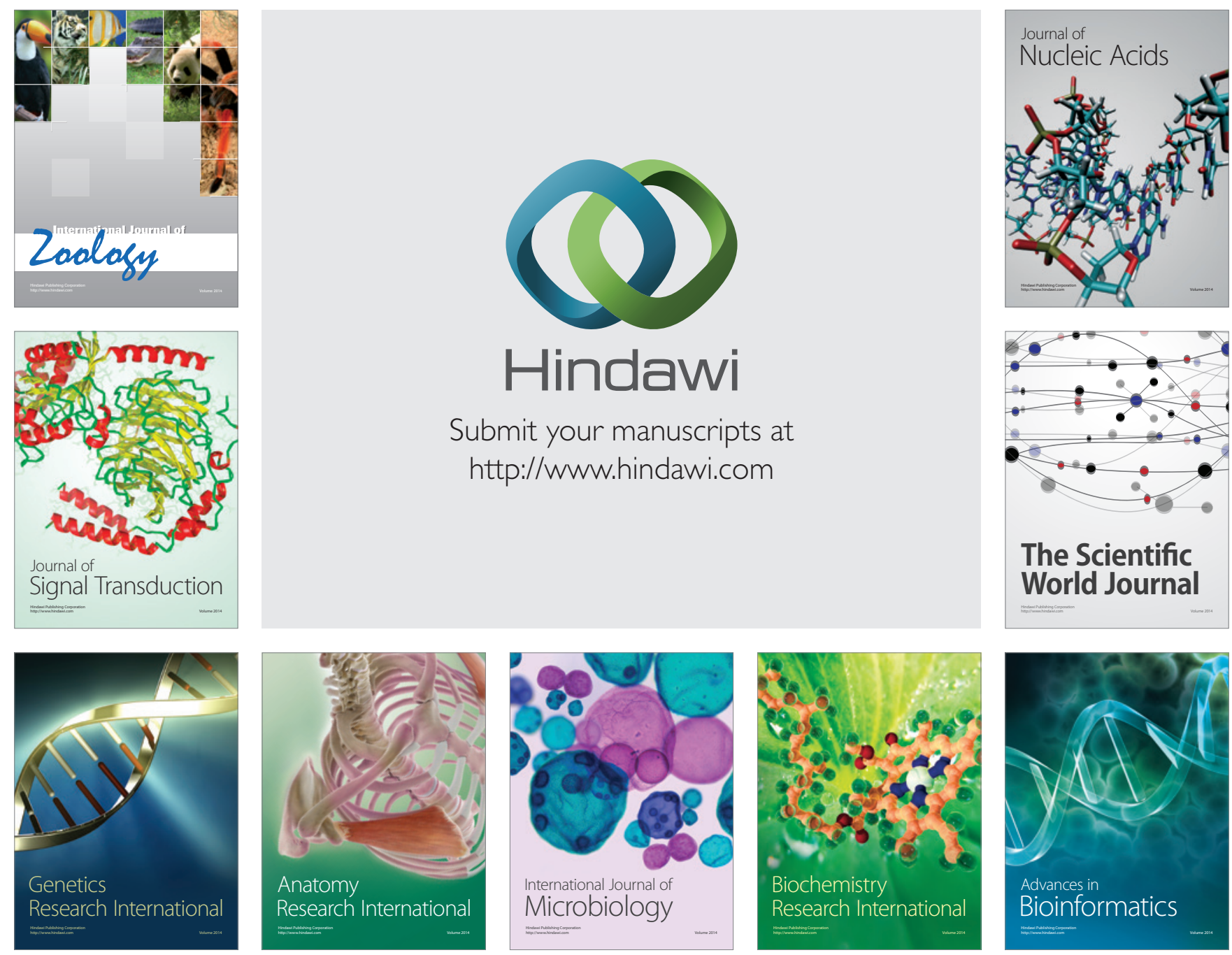

The Scientific World Journal
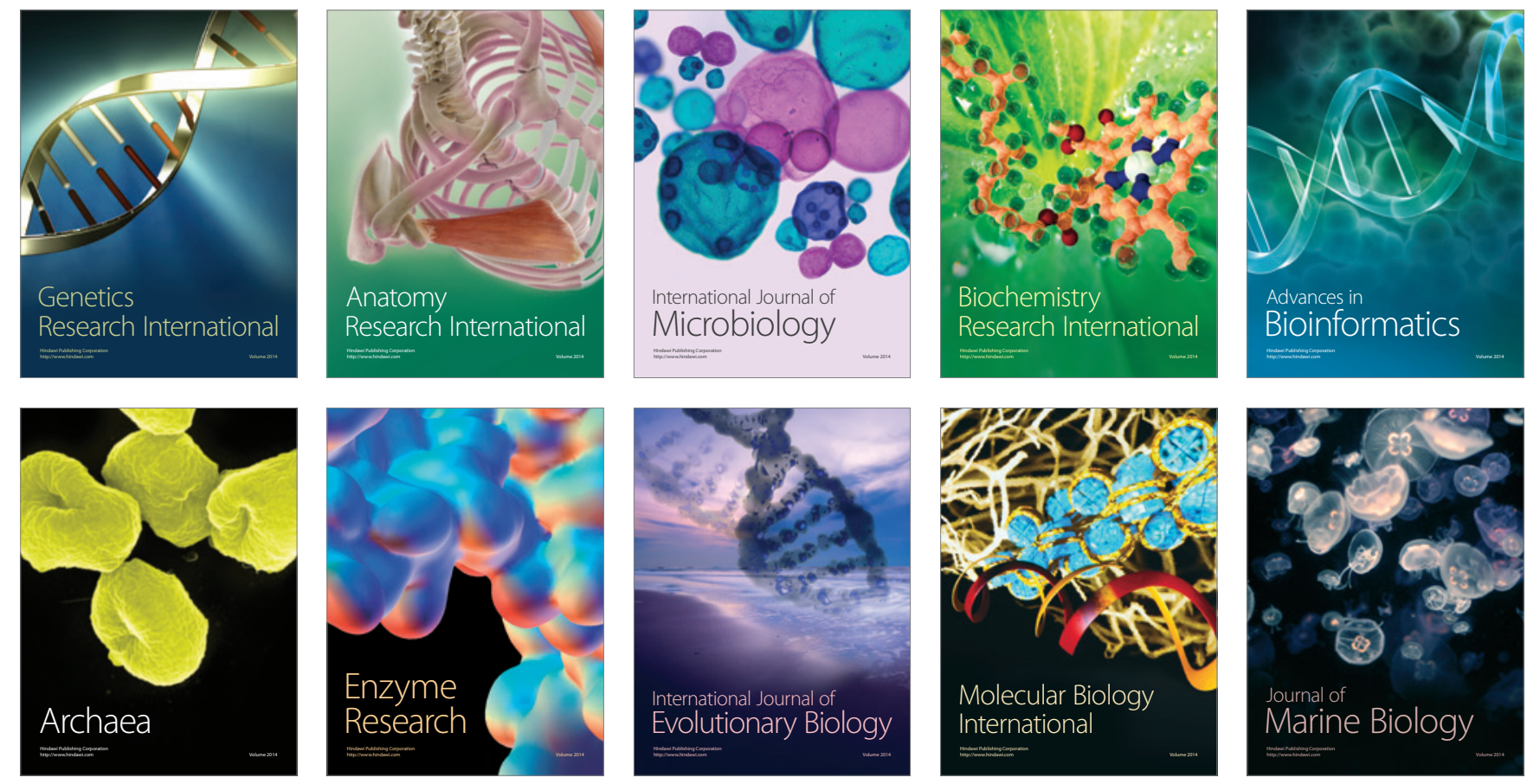